\title{
Impact of Agricultural Credit on Yield and Income of Paddy and Sugarcane
}

\author{
G. Uthamalingam ${ }^{*}$, K. R. Ashok ${ }^{2}$, M. Chinnadurai ${ }^{1}$, K. Mahendran ${ }^{3}$ \\ and M. R. Duraisamy ${ }^{4}$ \\ ${ }^{1}$ Department of Agricultural Economics, TNAU, Coimbatore, India \\ ${ }^{2}$ Director CARDS, TNAU, Coimbatore, India \\ ${ }^{3}$ Department of Agricultural and Rural Management, TNAU, Coimbatore, India \\ ${ }^{4}$ Department of Physical Sciences and Information Technology, TNAU, Coimbatore, India \\ *Corresponding author
}

Keywords

Credit gap,

Constraints,

Paddy, Sugarcane

Article Info

Accepted:

08 January 2020

Available Online:

10 February 2020

\section{A B S T R A C T}

An attempt has been made to assess the impact of agricultural credit on yield and income of sugarcane and paddy in Erode district of Tamil Nadu. The study shows the major contributor of input to the total cost was human labour, fertilizer \& manure and irrigation charges for both borrower-and non-borrower farmers. There exists gap between scale of finance and required working capital in the study area. The findings also showed that the cost of cultivation as well as the yield were higher in the case of borrower category compared to non-borrower category. It also confirmed that agricultural credit had positive impact on the crop production in the study area. Based on the results, appropriate policies were suggested to improve the lending system.

\section{Introduction}

Agriculture remains a dominant sector of the Indian economy. It has undergone structural changes during the period between 1970 and 2018. The GDP share of agriculture has fallen from $43 \%$ to $14 \%$ during the above period. Though there is no reduction in Agricultural GDP in absolute terms, the contribution in terms of percentage to total GDP has declined due to rapid growth in other sectors like the service sector and industries sector. As for employment, 55 percent of the total workforce is engaged in Agriculture as per the 2011 census. The food grain production has touched a level of 251.57 million tonnes during the year 2017-18 as per the Annual Report of Ministry of Agriculture, Cooperation and Farmers Welfare, Government of India for the year 2017-18. Further agricultural exports constituted a fifth of the total exports of the country. 
Institutional credit for agriculture has played a major role in registering such a phenomenal achievement (Thorat, Y. S. P., 2006; Arivarasan, S., Felix, K. T., \& AK, R. K., 2019). The flow of short-term agricultural credit has increased from Rs $32,355 \mathrm{cr}$ in 2000-2001 to Rs. $2,17,126$ cr in 2009-10.

With the enhanced flow of credit, food production has increased significantly. However, the profitability of farming enterprise has not increased proportionately in general and small and marginal farmers in particular. The agricultural sector still faces challenges such as lack of capital formation, regional disparity, dependence on noninstitutional sources with a high rate of interest especially by small and marginal farmers, tenant farmers/sharecroppers, etc (Randhawa, N. S., \& Sundaram, K. V., 1990).

Not with standing various financial sector reforms, the non-availability of adequate and timely credit from Institutional credit agencies said to be one of the major constraints encountered by the marginalized farmers (Kumar, R., 2005; Khan, N., Shafi, M. M., Shah, M., Islam, Z., Arif, M., Javed, R., \& Shah, N., 2011).

Both farmers and banks are comfortable with short term loans without recognizing the need for investment credit for enhancing profitability. Farmers tend to use short term resources for long term purposes making the investment infructuous.

In view of the reasons stated above, it has been attempted to study the impact of institutional agricultural credit on the yield and income of small and marginal farmers. Besides an analysis of assessment of the credit gap and problems involved in availing credit were made to evolve suitable remedial measures.

\section{Materials and Methods}

Erode district of Tamil Nadu was purposively selected for this study taking into account the area under production and productivity of the crop. The district ranks first in productivity among various districts of Tamil Nadu with an average production of 121 tonnes per hectare during the year 2017-18.

Though the district occupies 5.08 percent of the total area under the crop, it contributes 6.16 percent of the total production of the state. Similarly, in the case of paddy cultivation, the Erode district contributes a significant share in area and production. Hence the district was selected for the study.

A multistage random sampling technique was adopted for the selection of blocks, villages and sample respondents in the villages. The Primary data were collected for 60 samples for each crop (30 borrowers and 30 nonborrowers) through the personal interview method with the help of the Interview schedule.

\section{Cost concepts}

Costs are generated following certain cost concepts. These cost concepts and the items of costs included under each concept are given below:

Cost Al

i. Value of hired human labour.

ii. Value of hired bullock labour.

iii. Value of owned bullock labour.

iv. Value of owned machinery labour.

v. Hired machinery charges.

vi. Value of seed (both farm produced and purchased).

vii. Value of insecticides and pesticides.

viii. Value of manure (owned and purchased).

ix. Value of fertilizer. 
x. Depreciation on implements and farm buildings.

xi. Irrigation charges.

xii. Land revenue, cesses and other taxes.

xiii. Interest on working capital.

xiv. Miscellaneous expenses (Artisans etc.).

Cost $\mathrm{A} 2 \quad$ Cost $\mathrm{A} 1+$ rent paid for leased in land.

Cost $\mathrm{Bl} \quad$ Cost $\mathrm{Al}+$ interest on value of owned fixed capital assets (excluding land).

Cost B2 Cost B1+ rental value of owned land (net of land revenue) and rent paid for leased-in land.

Cost $\mathrm{Cl}$ Cost $\mathrm{Bl}+$ imputed value of family labour.

Cost $\mathrm{C} 2$ Cost $\mathrm{B} 2+$ imputed value of family labour.

Cost $\mathrm{C} 2 * \quad$ Cost $\mathrm{C} 2$ adjusted to take into account valuation of human labour at market rate or statutory minimum wage rate whichever is higher.

Cost $\mathrm{C} 3$ Cost $\mathrm{C} 2 *+$ value of management input at 10 percent of total cost $(\mathrm{C} 2 *)$.

\section{Garett's ranking technique}

Garett's Ranking Technique was adopted to analyse the reason for not availing institutional credit by non-borrowers. In this technique, the rank order was given in a sample ordinal scale. In this technique, the farmers were asked to rank the different reasons for not availing institutional credit.

Then they were arranged in ascending order according to the rank assigned. (Dhanavandan, S., 2016).The order of merit given by the respondents was converted into score by using the following formula,

Per cent position $=100\left(\mathrm{R}_{\mathrm{ij}}-0.5\right) / \mathrm{N}_{\mathrm{j}}$

Where,

$\mathrm{R}_{\mathrm{ij}}=$ Rank given for $\mathrm{i}^{\text {th }}$ Factor by $\mathrm{j}^{\text {th }}$ Individual
$\mathrm{N}_{\mathrm{j}}=$ Number of Factors ranked by $\mathrm{j}^{\text {th }}$ individual

The percent position of each rank thus obtained was converted into scores by referring to the table given by Garret. For each factor, the scores of individual respondents are added together and divided by the total number of respondents from whom the scores are added. The mean score was thus estimated and these mean scores for all the factors were arranged in descending order and factor with the highest mean score was given the first rank. The most important factors were thus identified and ranked.

\section{Results and Discussion}

\section{Cost of cultivation of borrower and non- borrower farms (Sugarcane and Paddy)}

A comparative analysis of cost and returns based on cost concepts of sugarcane and paddy crops in the study area were made to study the impact of credit on income. To the compare the net income between borrowerand non-borrower, cost and returns were calculated. Thereafter, the percentage difference between above mentioned categories were worked out. It is evident from Table 1, The average C2 (revised) cultivation cost of borrower sugarcane farm is ₹ $1,81,513.19$.

Cost A1 contributes 62.09 percent to revised C2, similarly 62.24 per cent, 67.51 per cent, 87.07 per cent, 79.27 per cent and 98.83 per cent were contributed by A2, B1, B2, C1 and $\mathrm{C} 2$ respectively. In the case of Paddy, the revised $\mathrm{C} 2$ cultivation cost was ₹ $78,879.52$.

The percentage share of A1 to revised C2 was $59.72 \%$. Similarly, percentage share of A2, B1, B2, C1 and C2 are 59.93 per cent, 65.18 per cent, 86.18per cent, 74.70 per cent and 95.71 per cent respectively. 
Table.1 Cost of cultivation of borrower farms (Sugarcane and Paddy)

\begin{tabular}{|l|l|r|r|r|r|r|}
\hline SI No & Particulars & \multicolumn{1}{l|}{ Cost } & \multicolumn{1}{|c|}{ Sugarcane } & \multicolumn{1}{c|}{$\%$} & \multicolumn{1}{c|}{ Paddy } & \multicolumn{1}{l|}{$\boldsymbol{l}$} \\
\hline $\mathbf{1 . 1}$ & Cost of Cultivation & A1 & 112708.10 & 62.09 & 47107.74 & 59.72 \\
\hline $\mathbf{1 . 2}$ & (Rs./Hectare) & A2 & 112974.30 & 62.24 & 47276.36 & 59.93 \\
\hline $\mathbf{1 . 3}$ & & B1 & 122546.90 & 67.51 & 51410.00 & 65.18 \\
\hline $\mathbf{1 . 4}$ & & $\mathbf{B 2}$ & 158050.60 & 87.07 & 67980.16 & 86.18 \\
\hline $\mathbf{1 . 5}$ & & $\mathbf{C 1}$ & 143883.30 & 79.27 & 58922.46 & 74.70 \\
\hline $\mathbf{1 . 6}$ & & $\mathbf{C 2}$ & 179387.00 & 98.83 & 75492.62 & 95.71 \\
\hline $\mathbf{1 . 7}$ & & C2 Revised & $1,81,513.19$ & 100.00 & 78879.52 & 100.00 \\
\hline & Yield (Qtl./Hectare) & & 933.12 & & 47.29 & \\
\hline & Income (₹/Hectare) & & $2,89,267.20$ & & 85,122 & \\
\hline
\end{tabular}

It is evident from Table 2, The average $\mathrm{C} 2$ (revised) cultivation cost of non- borrower sugarcane farm is ₹ $1,70,944.15$. Cost A1 contributes 58.80 percent to revised $\mathrm{C} 2$, similarly 58.96 per cent, 64.56 per cent, 85.33 per cent, 76.92 per cent and 97.68 per cent were contributed by A2, B1, B2, C1 and C2 respectively. In the case of Paddy, the revised C2 cultivation cost was ₹ $69,609.84$. The percentage share of A1 to revised $\mathrm{C} 2$ was 57.36 per cent. Similarly, percentage share of $\mathrm{A} 2, \mathrm{~B} 1, \mathrm{~B} 2, \mathrm{C} 1$ and $\mathrm{C} 2$ are 57.60 per cent, 63.54 per cent, 87.35 per cent, 74.12 per cent and 97.92 per cent respectively.

Table.2 Cost of cultivation of non-borrower farms (Sugarcane and Paddy)

\begin{tabular}{|r|l|l|r|r|r|r|}
\hline SI No & Particulars & \multicolumn{1}{l|}{ Cost } & \multicolumn{1}{c|}{ Sugarcane } & \multicolumn{1}{c|}{ P } & \multicolumn{1}{c|}{ Paddy } & \multicolumn{1}{c|}{$\%$} \\
\hline I-1.1 & Cost of Cultivation & A1 & 100521.01 & 58.80 & 39930.12 & 57.36 \\
\hline $\mathbf{1 . 2}$ & (Rs./Hectare) & $\mathbf{A 2}$ & 100787.22 & 58.96 & 40098.75 & 57.60 \\
\hline $\mathbf{1 . 3}$ & & $\mathbf{B 1}$ & 110359.80 & 64.56 & 44232.38 & 63.54 \\
\hline $\mathbf{1 . 4}$ & & $\mathbf{B 2}$ & 145863.55 & 85.33 & 60802.55 & 87.35 \\
\hline $\mathbf{1 . 5}$ & & $\mathbf{C 1}$ & 131482.82 & 76.92 & 51594.58 & 74.12 \\
\hline $\mathbf{1 . 6}$ & & $\mathbf{C 2}$ & 166986.57 & 97.68 & 68164.75 & 97.92 \\
\hline $\mathbf{1 . 7}$ & & $\mathbf{C 2}$ Revised & $1,70,944.15$ & 100.00 & $69,609.84$ & 100.00 \\
\hline & Yield (Qtl./Hectare) & & 814.61 & & 42.82 & \\
\hline & Income (₹/Hectare) & & $2,52,530$ & & $77,069.46$ & \\
\hline
\end{tabular}

Hence it can be inferred from Tables 1 and 2 that the cost and income of borrower farmers were higher for both crops compared to the non-borrower category. Hence it can be concluded that crop loan amount may be a vital reason for the higher cost of cultivation and higher income of borrower category.

Cost of production of borrower and nonborrower farms (Sugarcane and Paddy)

It is evident from Table 3, the average C3 
production cost per quintal of borrower sugarcane farm is ₹ 201.52. Cost A1 contributes 53.46 percent to $\mathrm{C} 3$, similarly 53.60 per cent, 58.69 per cent, 77.57 per cent, 69.92 per cent, 88.80 per cent and 90.91 per cent were contributed by A2, B1, B2, C1, C2 and $\mathrm{C} 2$ (revised) respectively. In the case of
Paddy, C3 production cost was ₹ 1619.18 . The percentage share of A1 to C3 was 52.15 per cent. Similarly, percentage share of A2, $\mathrm{B} 1, \mathrm{~B} 2, \mathrm{C} 1, \mathrm{C} 2$ and $\mathrm{C} 3$ are 52.37 per cent, 57.77 per cent, 79.41 per cent, 67.38 per cent, 89.02 per cent and 90.91 per cent respectively.

Table.3 Cost of production of borrower farms (Sugarcane and Paddy)

\begin{tabular}{|l|l|l|l|l|l|l|}
\hline S. No. & Particulars & Cost & Sugarcane & \% & Paddy & \% \\
\hline $\mathbf{2 . 1}$ & Cost of Production & A1 & 107.72 & 53.46 & 844.37 & 52.15 \\
\hline $\mathbf{2 . 2}$ & (Rs./Qtl) & A2 & 108.01 & 53.60 & 847.93 & 52.37 \\
\hline $\mathbf{2 . 3}$ & & B1 & 118.27 & 58.69 & 935.34 & 57.77 \\
\hline $\mathbf{2 . 4}$ & & B2 & 156.32 & 77.57 & 1285.74 & 79.41 \\
\hline $\mathbf{2 . 5}$ & & C1 & 140.91 & 69.92 & 1091.02 & 67.38 \\
\hline $\mathbf{2 . 6}$ & & C2 & 178.96 & 88.80 & 1441.42 & 89.02 \\
\hline $\mathbf{2 . 7}$ & & C2 Revised & 183.19 & 90.91 & 1471.98 & 90.91 \\
\hline $\mathbf{2 . 8}$ & & C3 & 201.51 & 100.00 & 1619.18 & 100.00 \\
\hline
\end{tabular}

Table 4 reveals that the average $\mathrm{C} 3$ production cost per quintal of non-borrower sugarcane farms is ₹ 210.24. Cost A1 contributes 56.15 percent to $\mathrm{C} 3$, similarly 56.32 per cent, 61.20 per cent, 79.25 per cent, 71.80 per cent, 89.84 per cent and 90.91 per cent were contributed by A2, B1, B2, C1, C2 and $\mathrm{C} 2$ (revised) respectively. In the case of
Paddy, C3 production cost was ₹ 1750.91 . The percentage share of A1 to C3 was 54.19 per cent. Similarly, percentage share of A2, $\mathrm{B} 1, \mathrm{~B} 2, \mathrm{C} 1, \mathrm{C} 2$ and $\mathrm{C} 3$ are 54.37 per cent, 59.27 per cent, 78.33 per cent, 67.95 per cent, 87.01 per cent and 90.91 per cent respectively.

Table.4 Cost of production of non-borrower farms (Sugarcane and Paddy)

\begin{tabular}{|l|l|c|r|r|r|r|}
\hline SI No & Particulars & Cost & Sugarcane & \% & Paddy & \% \\
\hline $\mathbf{2 . 1}$ & Cost of Production & A1 & 118.05 & 56.15 & 948.86 & 54.19 \\
\hline $\mathbf{2 . 2}$ & (Rs./Qtl) & A2 & 118.41 & 56.32 & 951.95 & 54.37 \\
\hline $\mathbf{2 . 3}$ & & $\mathbf{B 1}$ & 128.66 & 61.20 & 1037.83 & 59.27 \\
\hline $\mathbf{2 . 4}$ & & $\mathbf{B 2}$ & 166.61 & 79.25 & 1371.54 & 78.33 \\
\hline $\mathbf{2 . 5}$ & & $\mathbf{C 1}$ & 150.95 & 71.80 & 1189.83 & 67.95 \\
\hline $\mathbf{2 . 6}$ & & $\mathbf{C 2}$ & 188.89 & 89.84 & 1523.54 & 87.01 \\
\hline $\mathbf{2 . 7}$ & & $\mathbf{C 2}$ Revised & 191.13 & 90.91 & 1591.74 & 90.91 \\
\hline $\mathbf{2 . 8}$ & & $\mathbf{C 3}$ & 210.24 & 100.00 & 1750.91 & 100.00 \\
\hline
\end{tabular}


Table.5 Operational and fixed cost of borrower farms (Sugarcane and Paddy)

\begin{tabular}{|c|c|c|c|c|}
\hline SI No & Particulars & & Sugarcane & Paddy \\
\hline 3 & Operational Cost & & $\begin{array}{c}\text { 133305.39 } \\
(74.31)\end{array}$ & $\begin{array}{c}\mathbf{5 4 0 1 0 . 7 8} \\
(71.54)\end{array}$ \\
\hline 3.1.1 & Human Labour & Family & $\begin{array}{c}21336.38 \\
(16.01)\end{array}$ & $\begin{array}{c}7512.45 \\
(13.91)\end{array}$ \\
\hline 3.1 .2 & & Attached & $\begin{array}{c}2645.03 \\
(1.98)\end{array}$ & $\begin{array}{l}206.98 \\
(0.38)\end{array}$ \\
\hline 3.1.3 & & Casual & $\begin{array}{c}65771.56 \\
(49.34)\end{array}$ & $\begin{array}{c}14678.69 \\
(27.18)\end{array}$ \\
\hline 3.1 .4 & & Total & $\begin{array}{c}89752.97 \\
(67.33)\end{array}$ & $\begin{array}{c}22398.12 \\
(41.47)\end{array}$ \\
\hline 3.2.1 & Animal Labour & Hired & $\begin{array}{c}1279.24 \\
(0.96)\end{array}$ & $\begin{array}{l}82.94 \\
(0.15)\end{array}$ \\
\hline 3.2 .2 & & Owned & $\begin{array}{c}18.9 \\
(0.01)\end{array}$ & $\begin{array}{c}19.6 \\
(0.04)\end{array}$ \\
\hline 3.2.3 & & Total & $\begin{array}{c}1298.14 \\
(0.97)\end{array}$ & $\begin{array}{l}102.54 \\
(0.19)\end{array}$ \\
\hline 3.3.1 & Machine Labour & Hired & $\begin{array}{c}3848.54 \\
(2.89)\end{array}$ & $\begin{array}{c}9056.04 \\
(16.77)\end{array}$ \\
\hline 3.3.2 & & Owned & $\begin{array}{c}1115.36 \\
(0.84)\end{array}$ & $\begin{array}{l}775.67 \\
(1.44)\end{array}$ \\
\hline 3.3.3 & & Total & $\begin{array}{c}4963.9 \\
(3.72)\end{array}$ & $\begin{array}{c}9831.71 \\
(18.2)\end{array}$ \\
\hline 3.4 & Seed & & $\begin{array}{c}5336.72 \\
(4.00)\end{array}$ & $\begin{array}{c}6883.96 \\
(12.75)\end{array}$ \\
\hline 3.5.1 & Fertilizer \& Manure & Fertilizer & $\begin{array}{c}10074.93 \\
(7.56)\end{array}$ & $\begin{array}{c}5809.99 \\
(10.76)\end{array}$ \\
\hline 3.5.2 & & Manure & $\begin{array}{c}2770.67 \\
(2.08)\end{array}$ & $\begin{array}{c}2033.89 \\
(3.77)\end{array}$ \\
\hline 3.5.3 & & Total & $\begin{array}{c}12845.6 \\
(9.64)\end{array}$ & $\begin{array}{l}7843.88 \\
(14.52)\end{array}$ \\
\hline 3.6 & Insecticides & & $\begin{array}{l}839.25 \\
(0.63)\end{array}$ & $\begin{array}{l}1486.73 \\
(2.75)\end{array}$ \\
\hline 3.7 & Irrigation Charges & & $\begin{array}{c}11682.39 \\
(8.76)\end{array}$ & $\begin{array}{c}4011.25 \\
(7.43)\end{array}$ \\
\hline 3.8 & Miscellaneous & & $\begin{array}{c}0 \\
(0)\end{array}$ & $\begin{array}{l}43.55 \\
(0.08)\end{array}$ \\
\hline 3.9 & Interest on Working Capital & & $\begin{array}{c}6586.42 \\
(4.94)\end{array}$ & $\begin{array}{c}1409.04 \\
(2.61)\end{array}$ \\
\hline 4 & Fixed Costs & & $\begin{array}{c}\mathbf{4 6 0 8 1 . 6 1} \\
(25.69)\end{array}$ & $\begin{array}{c}\mathbf{2 1 4 8 1 . 8 4} \\
(28.46)\end{array}$ \\
\hline 4.1 & Rental Value of Owned Land & & $\begin{array}{c}35237.54 \\
(76.47)\end{array}$ & $\begin{array}{c}16401.54 \\
(76.35)\end{array}$ \\
\hline 4.2 & Rent Paid for Leased-in-Land & & $\begin{array}{l}266.21 \\
(0.58)\end{array}$ & $\begin{array}{c}168.63 \\
(0.78)\end{array}$ \\
\hline 4.3 & Land Revenue, Taxes, Cesses & & $\begin{array}{l}12.85 \\
(0.03)\end{array}$ & $\begin{array}{c}7.52 \\
(0.04)\end{array}$ \\
\hline 4.4 & $\begin{array}{l}\text { Depreciation on Implements } \\
\text { \& Farm Building }\end{array}$ & & $\begin{array}{l}726.22 \\
(1.58)\end{array}$ & $\begin{array}{c}601.89 \\
(2.8)\end{array}$ \\
\hline 4.5 & Interest on Fixed Capital & & $\begin{array}{c}9838.79 \\
(21.35)\end{array}$ & $\begin{array}{c}4302.26 \\
(20.03)\end{array}$ \\
\hline 5 & Total Cost $[3+4]$ & & $\begin{array}{c}\mathbf{1 7 9 3 8 7} \\
(100)\end{array}$ & $\begin{array}{c}\mathbf{7 5 4 9 2 . 6 2} \\
(100)\end{array}$ \\
\hline
\end{tabular}


Table.6 Operational and fixed cost of non-borrower farms (Sugarcane and Paddy)

\begin{tabular}{|c|c|c|c|c|}
\hline SI No & Particulars & & Sugarcane & Paddy \\
\hline 3 & Operational Cost & & $\begin{array}{l}122119.08 \\
(72.6)\end{array}$ & $\begin{array}{c}47861.17 \\
(69.02)\end{array}$ \\
\hline 3.1.1 & Human Labour & Family & $\begin{array}{c}21123.02 \\
(17.3)\end{array}$ & $\begin{array}{l}7362.2 \\
(15.38)\end{array}$ \\
\hline 3.1.2 & & Attached & $\begin{array}{c}2512.78 \\
(2.06)\end{array}$ & $\begin{array}{c}193.11 \\
(0.4)\end{array}$ \\
\hline 3.1.3 & & Casual & $\begin{array}{c}56563.54 \\
(46.32)\end{array}$ & $\begin{array}{c}11889.74 \\
(24.84)\end{array}$ \\
\hline 3.1.4 & & Total & $\begin{array}{l}80199.34 \\
(65.67)\end{array}$ & $\begin{array}{c}19445.05 \\
(40.63)\end{array}$ \\
\hline 3.2.1 & Animal Labour & Hired & $\begin{array}{c}1247.26 \\
(1.02)\end{array}$ & $\begin{array}{l}80.04 \\
(0.17)\end{array}$ \\
\hline 3.2 .2 & & Owned & $\begin{array}{l}19.66 \\
(0.02)\end{array}$ & $\begin{array}{l}20.03 \\
(0.04)\end{array}$ \\
\hline 3.2.3 & & Total & $\begin{array}{c}1266.92 \\
(1.04)\end{array}$ & $\begin{array}{l}100.07 \\
(0.21)\end{array}$ \\
\hline 3.3.1 & Machine Labour & Hired & $\begin{array}{c}3142.72 \\
(2.57)\end{array}$ & $\begin{array}{c}5976.99 \\
(12.49)\end{array}$ \\
\hline 3.3.2 & & Owned & $\begin{array}{c}1130.98 \\
(0.93)\end{array}$ & $\begin{array}{c}802.04 \\
(1.68)\end{array}$ \\
\hline 3.3.3 & & Total & $\begin{array}{c}4273.69 \\
(3.5)\end{array}$ & $\begin{array}{c}6779.03 \\
(14.16)\end{array}$ \\
\hline 3.4 & Seed & & $\begin{array}{c}5446.12 \\
(4.46)\end{array}$ & $\begin{array}{c}6956.24 \\
(14.53)\end{array}$ \\
\hline 3.5.1 & Fertilizer \& Manure & Fertilizer & $\begin{array}{c}9486.55 \\
(7.77)\end{array}$ & $\begin{array}{l}5674.04 \\
(11.86)\end{array}$ \\
\hline 3.5.2 & & Manure & $\begin{array}{c}2600.55 \\
(2.13)\end{array}$ & $\begin{array}{c}1965.96 \\
(4.11)\end{array}$ \\
\hline 3.5.3 & & Total & $\begin{array}{l}12087.1 \\
(9.9)\end{array}$ & $\begin{array}{l}7639.99 \\
(15.96)\end{array}$ \\
\hline 3.6 & Insecticides & & $\begin{array}{r}839.25 \\
(0.69)\end{array}$ & $\begin{array}{c}1486.73 \\
(3.11)\end{array}$ \\
\hline 3.7 & Irrigation Charges & & $\begin{array}{c}11420.24 \\
(9.35)\end{array}$ & $\begin{array}{c}4001.46 \\
(8.36)\end{array}$ \\
\hline 3.8 & Miscellaneous & & $\begin{array}{c}0 \\
(0)\end{array}$ & $\begin{array}{l}43.55 \\
(0.09)\end{array}$ \\
\hline 3.9 & Interest on Working Capital & & $\begin{array}{c}6586.42 \\
(5.39)\end{array}$ & $\begin{array}{c}1409.04 \\
(2.94)\end{array}$ \\
\hline 4 & Fixed Costs & & $\begin{array}{l}46081.61 \\
(27.4)\end{array}$ & $\begin{array}{c}21481.84 \\
(30.98)\end{array}$ \\
\hline 4.1 & Rental Value of Owned Land & & $\begin{array}{c}35237.54 \\
(76.47)\end{array}$ & $\begin{array}{c}16401.54 \\
(76.35)\end{array}$ \\
\hline 4.2 & Rent Paid for Leased-in-Land & & $\begin{array}{c}266.21 \\
(0.58)\end{array}$ & $\begin{array}{l}168.63 \\
(0.78)\end{array}$ \\
\hline 4.3 & Land Revenue, Taxes, Cesses & & $\begin{array}{l}12.85 \\
(0.03)\end{array}$ & $\begin{array}{c}7.52 \\
(0.04)\end{array}$ \\
\hline 4.4 & $\begin{array}{l}\text { Depreciation on Implements } \\
\text { \& Farm Building }\end{array}$ & & $\begin{array}{c}726.22 \\
(1.58)\end{array}$ & $\begin{array}{c}601.89 \\
(2.8)\end{array}$ \\
\hline 4.5 & Interest on Fixed Capital & & $\begin{array}{l}9838.79 \\
(21.35)\end{array}$ & $\begin{array}{c}4302.26 \\
(20.03)\end{array}$ \\
\hline 5 & Total Cost $[3+4]$ & & $\begin{array}{c}166986.57 \\
(100)\end{array}$ & $\begin{array}{c}68134.75 \\
(100)\end{array}$ \\
\hline
\end{tabular}


Comparative analysis of per quintal production cost between the borrower and non-borrower category indicates that per quintal production cost is higher for the nonborrower category. Though the cost of cultivation is higher for the borrower category it has a relatively lesser production cost. This high cultivation cost and lesser production cost of borrower category confirms that the borrower category yields more output compared to the non-borrower category.

This higher yield of borrower category may be the result of using the optimum level of input and timely purchase from the credit they got. These results are in line with the findings of Venu, B. N., Umesh, K. B., Kiran, R., \& Reddy, V. V. (2014) and Felix, K. T., Bharathi, R. D., \& Rajasekar, D. D. (2017).

\section{Operational and fixed cost of borrower and non-borrower farms (Sugarcane and Paddy)}

From Table 5, the share of operational cost to total sugarcane production cost in case of borrower farmers is $74.31 \%$ with a value of ₹ 133305.39. Among the operational cost, human labour occupies a major share $67.33 \%$ followed by fertilizer and manure $(9.64 \%)$, irrigation charges $(8.76 \%)$, interest on working capital (4.94\%), setts cost $(4.00 \%)$, machine labour $(3.72 \%)$, animal labour $(0.97 \%)$, insecticide $(0.63 \%)$. The share of fixed cost was $25.69 \%$ with ₹ 46081.61 .

Within the fixed cost, the rental value of owned land occupies a major share of $76.47 \%$ followed by interest on fixed capital (21.35\%), depreciation on implements \& farm building $(1.58 \%)$, rent paid for leased-in-land $(0.58 \%)$ and land revenue, taxes \& cesses $(0.03 \%)$. In the case of paddy cultivation, the share of operational cost to total paddy production cost is $71.54 \%$ with a value of ₹ 54010.78.
Within the operational cost, human labour occupies a major share $41.47 \%$ followed by fertilizer and manure (14.52\%), machine labour $(18.2 \%)$, seed cost $(12.75 \%)$, irrigation charges $(7.43 \%)$, insecticide $(2.75 \%)$, interest on working capital (2.61\%), animal labour $(0.19 \%)$. The share of fixed cost was $28.46 \%$ with ₹ 21481.84 .

Within the fixed cost, the rental value of owned land occupies a major share of $76.35 \%$ followed by interest on fixed capital $(20.03 \%)$, depreciation on implements \& farm building $(2.8 \%)$, rent paid for leased-in-land $(0.78 \%)$ and land revenue, taxes \& cesses $(0.04 \%)$.

From Table 6, the share of operational cost to total sugarcane production cost in case of non- borrower farmers is $72.60 \%$ with a value of ₹ 122119.08. Among the operational cost, human labour occupies a major share $65.67 \%$ followed by fertilizer and manure $(9.90 \%)$, irrigation charges $(9.35 \%)$, interest on working capital (5.39\%), setts cost $(4.46 \%)$, machine labour $(3.50 \%)$, animal labour $(1.04 \%)$, insecticide $(0.69 \%)$.

The share of fixed cost was $27.4 \%$ with ₹ 46081.61. Within the fixed cost, the rental value of owned land occupies a major share of $76.47 \%$ followed by interest on fixed capital $(21.35 \%)$, depreciation on implements $\&$ farm building (1.58\%), rent paid for leasedin-land $(0.58 \%)$ and land revenue, taxes \& cesses $(0.03 \%)$. In the case of paddy cultivation, the share of operational cost to total paddy production cost is $69.02 \%$ with a value of ₹ 47861.17.

Within the operational cost, human labour occupies a major share $40.63 \%$ followed by fertilizer and manure (15.96\%), seed cost (14.53\%), machine labour (14.16\%), irrigation charges $(8.36 \%)$, insecticide 
(3.11\%), interest on working capital $(2.94 \%)$, animal labour $(0.17 \%)$. The share of fixed cost was $30.98 \%$ with ₹ 21481.84 . Within the fixed cost, the rental value of owned land occupies a major share of $76.35 \%$ followed by interest on fixed capital (20.03\%), depreciation on implements \& farm building $(2.8 \%)$, rent paid for leased-in-land $(0.78 \%)$ and land revenue, taxes \& cesses $(0.04 \%)$.

It can be noted from Tables 5 and 6, the share of operational cost is higher for borrower farmers. It clearly indicates that non-borrower category farmers are using less inputs compared to borrowers. This may be due to the non-availability of credit.

\section{Difference between scale of finance and required working capital or credit gap}

The credit gap is estimated by arriving the difference between the operational cost of cultivation and the scale of finance approved by the State Level Bankers Committee.

Table.7 Percentage deviation between scale of finance and working capital

\begin{tabular}{|l|l|l|l|l|c|}
\hline Crop & $\begin{array}{l}\text { Scale of } \\
\text { finance } \\
\text { (ha) }\end{array}$ & $\begin{array}{l}\text { Working } \\
\text { capital } \\
\text { (ha) }\end{array}$ & Deviation & $\begin{array}{l}\text { Working capital } \\
\text { of efficient farmer }\end{array}$ & Deviation \\
\hline Sugarcane & 123500 & 133305.39 & $\begin{array}{c}9805.39 \\
(7.94)\end{array}$ & 149432 & 25932 \\
\hline Paddy & 68913 & 54010.78 & $\begin{array}{c}-14902.22 \\
(-21.62)\end{array}$ & 69320 & 407 \\
\hline
\end{tabular}

Note: Efficient farmers were identified from frontier analysis, Figures in the parenthesis indicates percentage deviation between scale of finance and working capital

It is noted from Table 7, as against the working capital requirement of Rs.1,33,305 per hectare the scale of finance is the per hectare is 1,23,500 leaving a gap of Rs.9805 or 7.94 per cent of the requirement. This result is in accordance with the results of Rani, S. P., Mani, K., \& Anjugam, M. (2016). In case of Paddy, scale of finance is well within the working capital requirement.

Though the scale of finance offered by commercial banks is adequate for paddy cultivation, a positive deviation was witnessed for efficient paddy farmers.

\section{Reasons for not availing institutional credit}

Usually, institutional credit helps the farmers to purchase quality inputs in adequate quantities which leads to increase in yield as well as the income of the farmer. Hence it is necessary to study the reasons or constraints in availing institutional agricultural credit.

The need for submitting many documents and lengthy procedure was ranked as the first constraint by the non-borrowers which prevented them from accessing institutional credit. Secondly delay in sanctioning the loan and untimely disbursement restrain them from approaching institutional credit.

Thirdly, rigid repayment norms and stringent recovery measures do not facilitate Institutional credit. High cost of credit and additional security followed by easy accessibility of credit from other sources and lack of awareness about availability of interest subsidy are the other reasons for not availing credit from banks. 
Table.8 Reasons for not availing institutional credit by non-borrowers sample households

\begin{tabular}{|l|l|l|l|}
\hline S.No & Reasons & No & Rank \\
\hline $\mathbf{1}$ & $\begin{array}{l}\text { Lack of awareness about interest subsidy } \\
\mathbf{2}\end{array}$ & 32 & VI \\
\hline $\mathbf{3}$ & $\begin{array}{l}\text { Roan from other sources was easily accessible. } \\
\text { procedure. }\end{array}$ & 38 & V \\
\hline $\mathbf{4}$ & $\begin{array}{l}\text { Delay in sanctioning loan and untimely } \\
\text { disbursement }\end{array}$ & 69 & II \\
\hline $\mathbf{5}$ & $\begin{array}{l}\text { Repayment schedule was not flexible } \\
\text { High cost of credit and requirement of security }\end{array}$ & 46 & III \\
\hline $\mathbf{6}$ & IV locuments \& lengthy & IV \\
\hline
\end{tabular}

Table.9 Suggestions for improvement in institutional lending system

\begin{tabular}{|c|c|c|c|}
\hline \multirow[t]{2}{*}{ S.No } & \multirow[t]{2}{*}{ Suggestions } & \multicolumn{2}{|c|}{ Borrower farm households } \\
\hline & & Score & Rank \\
\hline 1 & Reduction in the rate of interest for crop loans & 77 & I \\
\hline 2 & $\begin{array}{l}\text { Simplification of procedure to cover tenant and } \\
\text { share croppers }\end{array}$ & 55 & III \\
\hline 3 & Timely disbursement of Loan amount & 61 & II \\
\hline 4 & Flexibility in repayment & 48 & IV \\
\hline 5 & Increase in scale of finance & 32 & VI \\
\hline 6 & $\begin{array}{l}\text { Assessment of crop loss and settlement of claim on } \\
\text { individual basis. }\end{array}$ & 29 & VII \\
\hline 7 & Relaxation of security norms & 45 & $\mathbf{V}$ \\
\hline
\end{tabular}

\section{Suggestions for improvement in institutional lending system}

Many farmers suggested reduction in rate of interest, simplification of procedure, instant sanction of loan, flexible repayment period, assessment of crop loss and settlement of insurance claims on individual basis, increase in scale of finance, relaxation of security norms etc would facilitate them to approach Institutional financing agencies.

Thus, it revealed the existence of the gap in the demand and supply of credit. Reduction in the rate of interest applicable for crop loans, simplification of banking formalities for availing loans, settlement of insurance claims to all farmers suffering crop loss were the other suggestion given by sample farmers.
Further, timely disbursement of loan was another important factor responsible for proper and timely usage of agricultural inputs which would enhance the crop output.

\section{Conclusion and policy recommendations}

Borrower category farmers have high cultivation costs and yield compared to the non-borrower category. Increase in the yield has resulted in increase in income for borrower farmers. The findings of the study has confirmed positive impact of agricultural credit in the study area. The gap between the scale of finance and required working capital for efficient production was high in the study area. Hence, inadequacy of the loan amount is one of the major problems in purchasing adequate inputs, especially for sugarcane 
farmers. Therefore, banks may address the issue of under financing to the farmers and ensure all the needs of the farmers are met to reduce their dependency on the noninstitutional sources. Complicated procedure in getting loans is a major reason ranked by the non-borrower category for not availing the loan. Hence simplification of documents required is necessitated in such a way that the borrowers make a limited number of visits to the revenue offices and to the banks and thereby the transaction cost could be reduced.

\section{References}

Arivarasan, S., Felix, K. T., \& AK, R. K. (2019). Microfinance and Women Empowerment. Innovative Farming, 4(3), review-review.

Dhanavandan, S. (2016). Application of garret ranking technique: practical approach. International Journal of Library and Information Studies, 6(3), 135-140.

Felix, K. T., Bharathi, R. D., \& Rajasekar, D. D. (2017). Risk Aversion Behaviour of Dry Land Farmers in Tamil Nadu. Asian Journal of Agricultural Extension, Economics \& Sociology, 1-6.

Khan, N., Shafi, M. M., Shah, M., Islam, Z., Arif, M., Javed, R., \& Shah, N. (2011).
Review of past literature on agriculture credit in rural area of Pakistan. Sarhad Journal of Agriculture, 27(1), 103-110.

Kumar, R. (2005). Constraints facing Indian agriculture: Need for policy intervention. Indian Journal of Agricultural Economics, 60(902-201668022).

Randhawa, N. S., \& Sundaram, K. V. (1990). Small farmer development in Asia and the pacific: Some lessons for strategy formulation and planning (No. 87). Food \& Agriculture Org..

Rani, S. P., Mani, K., \&Anjugam, M. (2016). Evaluating the gap in demand and supply of institutional lending for paddy cultivation in Thiruvarur district of Tamil Nadu, India. Indian Journal of Agricultural Research, 50(2), 150-158.

Thorat, Y. S. P. (2006). Microfinance in India; Sectoral issues and challenges. Towards a sustainable microfinance outreach in India, 27-42.

Venu, B. N., Umesh, K. B., Kiran, R., \& Reddy, V. V. (2014). Impact of agricultural credit on income, employment input usage of borrower and non-borrower farm households in Chickballapur district of Karnataka. International Journal of Farm Sciences, 4(3), 185-194.

\section{How to cite this article:}

Uthamalingam. G, K. R. Ashok, M. Chinnadurai, K. Mahendran and Duraisamy. M. R. 2020. Impact of Agricultural Credit on Yield and Income of Paddy and Sugarcane. Int.J.Curr.Microbiol.App.Sci. 9(02): 1414-1424. doi: https://doi.org/10.20546/ijcmas.2020.902.164 